\title{
A Review of Power Infrastructure Financing: The Brazil and India Approach
}

\author{
Kasenge Mathe ${ }^{1}$, Ngcobo Ntebo ${ }^{2}$ and Emmanuel Oikelomen Ayorinde ${ }^{3, *}$ \\ ${ }^{1,2,3}$ Department of Civil Engineering Technology, University of Johannesburg, South Africa
}

\begin{abstract}
Infrastructure development promotes human capital development. Access to quality education and health care are some of the incentives of Infrastructure development. The development of power infrastructure in Brazil and India has greatly facilitated it gross domestic product (GDP) and socialeconomic development. This study assesses the approach of development of power infrastructure in Brazil and India as a prerequisite for other emerging nation's economy to follow. A confirmatory literature involving power infrastructure development in India and Brazil was explored for the purpose of this study. The paper highlights the challenges, policies effects, legislations effects, ways to finance, philosophical approach and the economic benefits involves in power infrastructure development in Brazil and India. Power infrastructure will strive when the challenges involves in its development is addressed. The adoption of this approach of implementing the developmental challenges, better policies, innovative financing scheme and effective legislations that has aided the development of power infrastructure development and should be replicated in emerging nations i.e. sub-Sahara Africa (SSA). In addition, direct implementation of this approach will bring forth the benefits of infrastructure development. This will contribute to the knowledge of power infrastructure development in emerging nations across the globe.
\end{abstract}

\section{Introduction (Brazil and the state of power infrastructutre development)}

Brazil occupy's an area of 8.5 million $\mathrm{km}^{2}$, with a growing population of 191 million people, with average income of US\$ 10,414 (Purchasing Power Parity- PPP, 2010), with GDP of 2.017 trillion, Brazil is the most developed country in the Latin America, according to the (1). Brazil power infrastructure facilities development can be traced back over 40 years down the line, after the fall in oil in the year 1970s, where there was decrease in the imports of oil and there was increased in the domestic production with mixed directives which brought about powerful growth of sugarcane ethanol, placing Brazil independent in the transportation sector European Journal on Power Electronics and Electrical Drives (2). Since 1990 the countries demand electricity has doubled, closing on 300 mtoe by 2013 and has exceeded the increased in the gross domestic products (GDP) to the average increase in growth which amounts to 3.1 per cent and that of GDP of 2.8 percent respectively. For the more than ten years in Brazil for the supply of energy; Natural gas, oil and it's subsequent has accounted for about 80 percent of the increase in energy supply for the past ten years in Brazil (3). According to (3), renewal energy mechanisms remains a solid aspect in the local fuel mix, which represents 41 percent in 2013, as against 60 percent in 1970, making Brazil with 1.55 Tco2/toe (CO2 intensity) emission element is the least carbon-intensive economy in the world as compared to the world average which is 2.37 tco $2 /$ toe.

Laws that help to improve the power infrastructure aspects of Brazil was made in the year 1988 during the military regime, which settle the ownership of both natural resources and hydraulic power potentials under the government and stated guild lines for negotiations and requirements to facilitates them. This process was not implemented until 1996 and later reviewed in 2002, and this government control over natural resources act has allowed Brazil as a nation to determine its power infrastructure development. Uncertainties have been the case of the players in the power infrastructure markets and investors, because of changes in legislations as relating to power infrastructure development in Brazil (4) Biomass, energy efficiency and hydropower have allowed Brazil to be among the least carbon-intensive economy in the world. The destabilization in the oil industry in the year 1975, led to the use bioethanol, with the compulsory use of 25 percent (E25), these bioethanol of "gasoline-bioethanol" mix, is Major elements in the increase in oil prices and economic development as a result of this over 90 percent of cars manufactured in Brazil are "flex-fuel" which either contains E25 or E100. The composition of bio-ethanol and bioenergy from sugar cane source amounts up to 17 percent of the primary power supply in the country (3).

The increase in the growth in the non-renewable provision of energy over the year 2000 s, specifically that

*Corresponding author: engrkulz@gmail.com 
of natural gas, is because of unfavorable weather conditions challenges to hydropower expansion. The effect of drought caused excessive blackouts in 2001; these have led to the building of gas plants to contain such excesses in the future (5). Also, about 70 percent of Brazil's hydropower capacity is constructed in the Amazon area (6). In the year 2002 a motivational program was created called the PROINFA, these in every case increased the competitions between the small hydropower, biopower, photovoltaic power (PV) and wind power plants. The Wind will be the next big thing from Brazil renewal energy drive as a result of drought, even if the wind performance is seasonal, few wind farms have recorded exceptional rise in capacity factors in the surplus of 50 percent (5). Wind farm development capacity in Brazil increased by 84 percent in 2013 (7).

\subsection{Challenges and Policies Affecting Power Infrastructure in Brazil}

Brazil with India, China, and Russia is the world top four emerging nations in terms of infrastructure development and an increase in GDP, these makes Brazil one of the best places for economic growth, due to the excessive increase in the power infrastructure facilities (8). For the past twenty years Brazil's growth has exceeded other nations in the world, these gave them the opportunity to host the FIFA World Cup in 2014 and Olympics in 2016, and has the opportunity to be among the G5 economy in the world, but these have since declined due to bad policies and inconsistency (8 and 9). (10 and 11) stated that due to the unfavorable economic policies and lack of preparedness to drought faced by hydroelectric facilities, which is the provider of about $71.58 \%$ of electricity in 2011, which declined to $61.96 \%$ due to drought as represented in fig. 1 the map of Brazil. This problem faced by the Brazil power sector has opened the door to other means of generating electricity, to meet the need of the growing population; these other sources are thermal power facilities which amount to $25.65 \%$ for 2011 , this makes Brazil $100 \%$ sufficient in terms of power infrastructure development, and later the thermal power facilities increased to $26.83 \%$ (10). These, however, demonstrated that Brazil needed to import from other nations to be sufficient in providing electricity for the citizens. Though Brazil boosts an increase in electricity consumption with about 3.3 increase between 2000 to 2011 , this is still lacking when compared to the world's two emerging nations, China and India with an increase in the rate of consumption of $4.3 \%$ and $5.4 \%$ (12). The problem of drought has made Brazil locate their hydroelectric facilities in the Amazon region; this is because of reduced amount of rainfall (12).

Brazil has the potential to produce about $260 \mathrm{GW}$ of electricity from all the sources of generating electricity in Brazil which includes; hydroelectric power facilities, which is the major provider of electricity in Brazil, thermal power plant which produces most of the energy capacity after hydroelectric facilities and wind farm which supplement the other sources of electricity to meet $100 \%$ sufficiency (10).

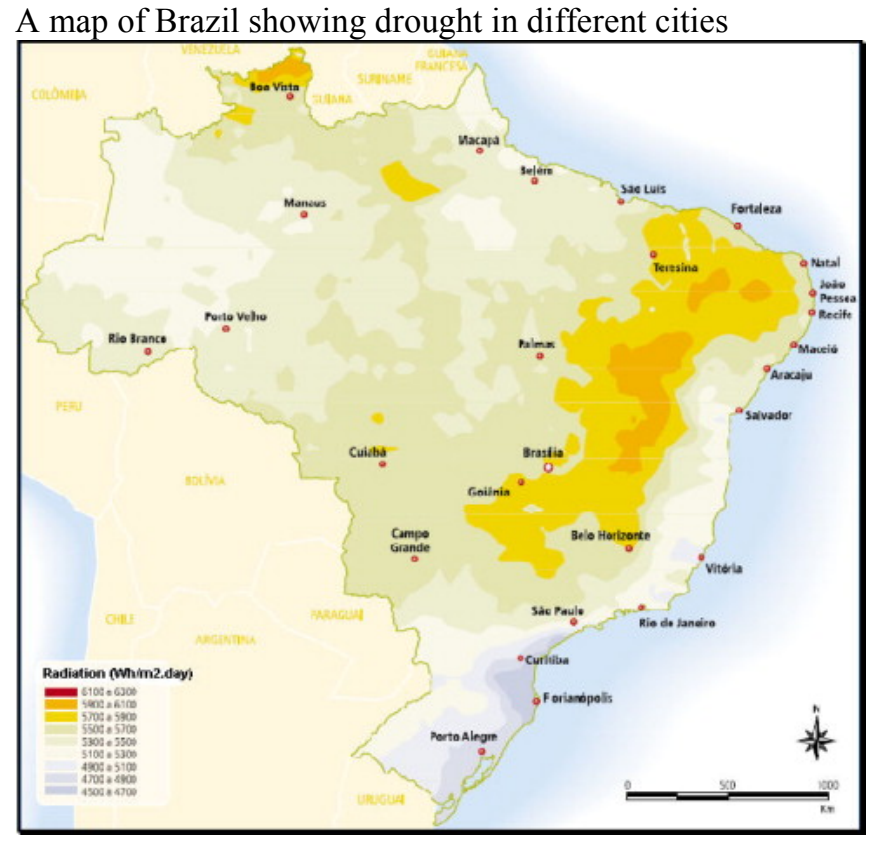

Fig.1. Source: (13)

\subsection{Present and Future Policies Situation}

The two important organizational deeds that have helped Brazil in the energy policymaking are both the long-term (14) and yearly-improved medium-term energy policy. The PNE 2030 was produced in 2007 and is expected to be updated for the year 2050 (16). While that of the medium-term policies PDE, expand to 2022 and it will include the following; affordable tariff prices, energy stability, reduction in the emissions of gasses, all-around access to power (16). For several years now, there have been different ways of financing infrastructure in Brazil, but not always work in funding for power infrastructure facilities. The decision taken to finance energy infrastructure is directed by a useful policy framework, which ensures funding gotten is cost effective (17). General infrastructure development investment in Brazil is spearhead by the Brazil Development Bank (BNDES). The bank decreases the circulation for infrastructure services the institution also prolong the agreement of some its grants ranging from US\$ 3.4 billion in 2003 to an increase of US\$ 17.5 billion in 2008 and US\$ 25 billion in 2009 for infrastructure development $(16 ; 18)$. Brazil policy since 1970, placed the "national energy planning and investment" on a yearly energy balance, made known by the Ministry of Mines and Energy. For the last decade now it is published by the Planning and Research sector "Empressa de Pesquisa Energetica" (19).

\subsection{Ways of Financing Power Infrastructure in Brazil}

The following according to (16) are the sources of power infrastructure financing in Brazil:

- Budgeting: it is gotten from electrobas and petrobas. This is the annual budgetting assigned for the purpose of developing power infrastructure projects in the country. 
This has however not been able to meet the demand and financial capacity of the brazil power sector, which has led to sourcing for other alternative sources in the financing of power infrastructure in Brazil (16).

- Global energy fund: these types of funding is obtained from the "global reversion reserve" and this is the expansion funding given for the purpose of improving and expanding power development global and also it supports renewable energy development (16).

- International finance: this is a source of financing power infrastructure projects mandated through Brazil electricity regulatory agency (ANNEL) to all power utilities company, asking them to spend $0.5 \%$ of their working revenue on power cost-effectiveness measures. This has however raked in US\$ 378m (16).

- National development banks (BNDES): the national development banks of Brazil has been the main means of financing power infrastructure projects in Brazil. And also, responsible for the granting of loans to the private investors investing in the power infrastructure sector in Brazil and approve finances on behalf of the Brazil government for the purpose of developing power infrastructure. By 2011 the BNDES has approved a total of US\$ $16.5 \mathrm{~m}$ as an credit efficiency loan to an power distribution company, for the purpose of improving and expansion of power infrastructure development (20).

- National climate finance: this is also known as Fundo Nacional Sobre Mudanga do Clima. This kind of financing mechanism is gotten from the ministry of Environment and jointly controlled by the National Development Bank (BNDES). This focuses on reduction and adaptation of the following seven factors; urban flexibility, sustainable municipality, productive equipment, low carbon energy sources, concrete waste and briquette. A total of US\$ $252 \mathrm{~m}$ was allocated through the budget, and partly gotten from petroleum resources for this purposes (20).

- Social Fund: this mechanism was enacted in 2010, and receives finances from petroleum resources. They are also used in the area of reduction and adaptation and other specific areas with the purpose of boosting development in power infrastructure (21).

Clean development mechanism (CDM): this has been used to finance quite a number of sustainable energy in Brazil. The Brazil government through the BNDES has created numbers of credit facilities for this purpose, this will however Improvement power development in the region (16).

\section{India and the State of Power Infrastructure Development}

Since the 1970s in India power infrastructure remained a natural monopoly whereby it was operated and financed by the traditional financiers, which is the government (4). From the early stage of the 1970s, the traditional operators and financiers of this model i.e. the central government was unable to meet the demands growing population of the citizens, this is what led to the general reforms and deregulation of the sector, which ushered concessions in executing power infrastructure development facilities as a means to meet the demand of the growing population in India (22). The power sector in India has improved significantly both in size and capacity over these years, from total existing generation ability of 1,362MW in 1947 to 147,966 in 2009 Ministry of power (23). The main reasons for the reform is $t$ to attain improvements in the areas of distribution and generation. The case of India power sector, policies was made to encourage the involvements of the private sector in investing in the power sector, as a means of meeting the demands of the populations in the area of energy stability (24). Despite the fact that there was a reform in 2004, that was set out to achieve low tariffs and also attracts private investments in the financing of power infrastructure developments; there has been little gains in the involvements of private investments in the power developmental projects. The power is still dominated by the public-owned utilities with very low involvements of private investments, examples are; in 2009 overall existing capacities was $1,47,715 \mathrm{MW}$ where $48,970 \mathrm{MW}$ (34 percent) was from the central government, $76,115 \mathrm{MW}$ (53 percent) was state-owned, and $22,625 \mathrm{MW}$ (13 percent) was private investment (25). The failure to boost private sector involvement in power infrastructure development has led to inefficiencies in the supply of electricity (26). In distribution, the citizens have not realized an increase in tariffs as the total losses continue to increase commercially, the average AT\&C loss in India is against that of developing countries which is 30 percent in India from 2007-08 and developing countries which is 10 to 12 percent respectively. It is also understandable that increased in competitions will boost efficiency and increase in the private investments in the power sector Priority Flow Control (27).

\subsection{Past and Present Situations of India power development}

In India to tackle the history problems of the provision of enough energy security for the entire citizen and improved economic development, this has led to the improving the capacity of renewable energy to the power sector systems for efficiency (28) the India government has undertaken a giant plan in building of $20,000 \mathrm{MW}$ of solar power by 2020 to boost the supply of electricity and directly improving the economy of the nation. India is known to be the fifth biggest wind farm turbines around the world, with total installations of $16 \mathrm{GW}$ by 2011 . This ambition of the India government is been put to the test due to the finances needed in the actualization of such giant stride, this is because the government alone cannot on its own undertake such projects, so therefore there is need for private investment in the power infrastructure development sector to actualize this objective in India (29).

According to (30) and (31) which stated that there will be the need of an around US\$ 1 trillion to be able to increase from 8 percent GDP of 2011-12 to 10 percent increase in GDP for 2016-17 for a five-year plan, therefore there is a gap of US\$ 300 billion in the infrastructure investment sector, and is as a result of non- 
availability of long-term capital. From the 1991 Act, the development financial institutions of India was the major financial of long-term capital for infrastructure development in which power infrastructure development is included, there has been decline in the role of the Development Financial Institutions (DFIs) due to the deregulations of financial markets, which has relegated the DFIs in competing with the commercial banks in the financial markets. This coupled with the naive corporate bond has a deepened the gap in the financing power infrastructure facilities (29). Historically, public owned utilities have always been the drivers of power infrastructure facilities in India and coupled with the decline in services given by the central government. There is a forecast of 94 percent of the $11^{\text {th }}$ plan of the 2007-12 target is aimed at getting from 230MW in 199495 to 16,078 at 2011 (32).

\subsection{Financing Power Infrastructure Facilities in India}

According to the Global trends in renewable (33), there are several investors involved in the financing of India power infrastructure developments, they are banks, legitimate companies, institutional financiers who can be public owned utilities or owned by two or three government of different countries. They are also financed by private finance and public finance, venture finance, and private equity finance. The returns of the investment by these bodies depend greatly on the where the capital is gotten from and the risk involved in a particular project, these usually depends on the duration of the power infrastructure project. The report of Bloomberg (28) showed that in the period between 2006 09, India's power infrastructure facilities investments was in between US\$ 4 billion and US\$ 5 billion, there has been great increase in the investment from that period, from US\$ 4.2 billion in 2009 to a rise of US\$ 12.3 billion in the year 2011 .

Table 1. Financing Infrastructure In Brazil

\begin{tabular}{|c|c|c|}
\hline Variable names & Definition & References \\
\hline Commercial banks & $\begin{array}{l}\text { these involves the provision of investment capital for power } \\
\text { infrastructure development in India, they give investment capital to } \\
\text { public sector banks, private sector banks, and foreign banks with the } \\
\text { aim of aiding power development and a boost in the economy of India } \\
\text { and its GDP }\end{array}$ & 29 \\
\hline Equity investors & $\begin{array}{l}\text { This is one the mechanisms of financing power infrastructure } \\
\text { developments in India, by providing finance in the form of private } \\
\text { equity and venture capital for the purpose to aid power facilities } \\
\text { development, for the purpose of energy sufficiency and growth in the } \\
\text { economy of India. }\end{array}$ & 34 \\
\hline Institutional investors & $\begin{array}{l}\text { This mechanism of financing power infrastructure facilities, provides } \\
\text { private finance as insurance finance to investors for the growth and } \\
\text { development of the sector and the economy }\end{array}$ & 34 \\
\hline Development Banks & $\begin{array}{l}\text { The development banks provide capital to the development financial } \\
\text { institutions in India though has declined in their capacity in the } \\
\text { delivery of capital investment for the development of infrastructure in } \\
\text { India still has a significant role in financing power infrastructure } \\
\text { delivery in the India and economic development }\end{array}$ & 29 \\
\hline $\begin{array}{l}\text { Public-Private } \\
\text { Partnership }\end{array}$ & $\begin{array}{l}\text { Though most of the shareholders of a public-private partnership are the } \\
\text { private sector, and a fewer representative from the public sector usually } \\
\text { a representative of either the federal government, state or local } \\
\text { government agencies (35). Example of a PPP project in India through } \\
\text { the Independent power project (IPP) was the Dabhol power project } \\
\text { (DPP), with government of India and ministry of power collaborated } \\
\text { with the Enron Development Corporation (EDC) in delivery this } \\
\text { massive project of } 2015 \mathrm{MW} \text { which will be attached to the Maharashtra } \\
\text { state electricity board (MSEB) network via } 440 \mathrm{KV} \text { transmission, the } \\
\text { Dabhol Power Company (DPC), a Special Purpose Vehicle (SPV) } \\
\text { served as medium in bringing together private investors and } \\
\text { government organizations in achieving this purpose. }\end{array}$ & 36 \\
\hline
\end{tabular}




\subsection{India Electricity Policies effects}

Proper and well-structured government policies on energy infrastructure development can pave the way for new way and mechanisms in financing power infrastructure facilities (37). A steady regulatory will be needed even with the various changes that come with political parties. The national electricity Act of India 2003 transformed the power industry, which about changes such as deregulation of the power generation, transmission, and distribution, these gave the state electricity regulatory commission (SERCs) the authority to set the procurement methods of the power sector (39 Ministry of Power, 2003). According to the study of (28), there is a mandate of improving the shares of the power industry in the energy supply chain. Presently in India, the government effective policies and incentives that support the different means of power infrastructure facilities (37). In India states, electricity regulatory commission (SERCs) has adopted some measures towards power development facilities and renewable purchase obligation (RPO). And despite these favorable policies in place by the state and central government, there has been a broad difference in the capacity of each state for instance, states like Tamil Nadu, Maharashtra, Gujarat and Karnataka wind capabilities is more than 1000MW while states like West Bengal and Kerala produces less than 50MW (29).

\subsection{Effects of Legislation on power infrastructure in India}

According to the report of (38), the following was identified as the policies that can affect the rate of the cash flow from investors in the financing of power infrastructure development.

\subsubsection{Time of revenue support}

This entails the length of rates or tariff, purchasing power rapport, or another source of financing support i.e. the more time given allows debts to be paid of gradually; with an efficient result, that reduces the financial burden all through the time of the project (38).

\subsubsection{Revenue certainty}

It is important to have a stable source of financing; this kind of support will offer more assurance of financing in the project (38).

\subsubsection{Risk perceptions}

There is high financial risk associated with power infrastructure development, due to the length of the projects. This is done to know the cost of the project with risky perceptions (38).

\subsubsection{Completion certainty}

this is done due to the cost of delays associated with power project completion rates brought by regulations delaying the completion of power infrastructure projects with the setback in realizing the financial benefits (38).

\subsubsection{Cost certainty}

Regulations can affect the cost of completion of a power infrastructure project, by adding extra requirements in the process of construction (38).

\subsection{Challenges of Power Development in India}

The following according to Reserve Bank of India, (39) are the challenges facing power infrastructure financing in the India context;

- Construction risk; the lower the construction risk in the financing of power infrastructure projects in India by an investor, the lower the pricing in the allocation of loans from the banks (39).

- Limited time for payment: In the India context, the time given for loan refunding on the power infrastructure projects is a period of five to ten years. This however is a challenge faced by investors in the India power industry due to the difficulty involved by foreign investors in assessing India power sector in 5 to 10 years (39).

- Currency risk: this is also a factor affecting the financing power infrastructure development in India; this is due to currency fluctuations, which can bring about great loss to investors. This is because the main aim of investors, investing in the sector is to make profit and currency risk can hinder their investments (39).

- Policy framework: favorable policy frame work needs to be enacted to guide the nature of power infrastructure financing in India, with the purpose of boosting development in the power industry of India (39).

- Political risk: due uncertainties surrounding politics globally, is a challenge in financing of power infrastructure projects. No private investors will be willing to invest in a political unstable atmosphere, as these might harm the investments (39).

\subsection{Economic Benefits of Power Development in India}

India located in Asia, a continent that house about 4.3 billion of the world and a home to four of the world biggest economy: China, India, Japan and Republic of Korea. Together these great countries account for about $30 \%$ of the world GDP (40). The development of power infrastructure in India has increased the economic growth in the country, undermining the fact that there are gaps in service delivering between the rural areas and urban centers with the rural centers having poor service delivery to the urban centers (41). India level of power infrastructure development has been credited with the improved economic growth in the country (30).

The government of India has made huge investments in large, medium and small irrigation facilities. The large facilities have been responsible for the availability of water provision, irrigation and hydroelectric power (42). 
Investments in the energy sectors have resulted to improvements in the life and standard of citizens, thereby eradicating poverty and boosting the economic growth of India (42).

\section{Research Methodology}

This study is carried out with respect to existing literature, from published researchers with the aim of reviewing the level approach of power infrastructure development in Brazil and India as a model to developing nations economy, inorder to develop their power infrastructure. This study mostly focuses on the power/energy infrastructure development in Brazil and India. In addition, this study reviewed power infrastructure literature on policies effects, challenges, ways of financing and effective legislation in Brazil and India, quantitative research methodology was used in carrying out this study. Also, the study reviewed literature relating to sustainble infrastructure growth in India, Brazil and emerging nations. This study reviewed a wide range of existing literature from the year 1997 to 2017 for a more robust study.

\section{Discussions of Findings from Literature}

This section discussed the understanding and mode of power infrastructure development in Brazil and India power industry. To understand power infrastructure development in the context of the country under review, a brief overview of the history were explored. The like terms between these countries (BRAZIL and INDIA) is that both are among the five emerging nations in the world (BRICS), and has put in place favorable policies that will transform the power sector.

Brazil power sector has emerged as the top renewal energy in the South American region. As one of the top five emerging nations in the world (BRICS), Brazil with $1.55 \mathrm{Tco} 2 /$ toe ( $\mathrm{CO} 2$ intensity) emission element is the least carbon-intensive economy in the world as compared to the world average which is $2.37 \mathrm{tco} 2 /$ toe is one of the top low carbon economy in the world due to effective renewable policies. In the year 2002 PROINFA, was created these in every case increased the competitions between the small hydropower, biopower, photovoltaic power (PV) and wind power plants. Because of drought that has affected the main source of electricity in Brazil, ensure that about 70 percent of hydroelectric power in Brazil are located in the Amazon area. This has made Wind farm the next big thing from Brazil renewal energy drive even if the wind performance is seasonal, few wind farms have recorded exceptional rise in capacity factors in the surplus of 50 percent. Wind farm development capacity in Brazil increased by 84 percent in 2013. Brazil economic growth because of power infrastructure facilities in the past 20 years gave them the opportunity of hosting the FIFA World Cup and Olympics in the year 2014 and 2016 respectively. In addition, these gave the opportunity to be among G5 economy in the world, it has long taken a nosedive due to recent unfavorable legislative regulation as regards to infrastructure development (Power). General infrastructure development investment in Brazil is sponsored by the Brazil Development Bank (BNDES). The bank decreases the circulation for infrastructure services the institution also prolong the agreement of some its grants ranging from US\$ 3.4 billion in 2003 to an increase of US\$ 17.5 billion in 2008 and US\$ 25 billion in 2009 for infrastructure development (43).

In India, power infrastructure was developed by the government as a natural monopoly from the 1970s. As the population grew over the years it became imperative for a concession in the financing of power infrastructure development, because central government no longer possess the capacity to finance the infrastructure solely. This led the government to collaborate with other partners and shareholder which has greatly improve the stock of India power sector significantly, both in size and capacity over these years, from total existing generation ability of 1,362MW in 1947 to 147,966 in 2009. In 2004, a reform was undertaken to achieve a low tariffs system and improve the participation of private investment. However, this has amounted to little gain, because there has been little benefits to that effect; the power development is still dominated by government owned utilities. In 2009 overall existing capacities was 1, $47,715 \mathrm{MW}$ where $48,970 \mathrm{MW}$ (34 percent) was from the central government, $76,115 \mathrm{MW}$ (53 percent) was stateowned, and $22,625 \mathrm{MW}$ (13 percent) was private investment. India is known to be the 5th biggest wind farm turbines around the world, with total installations of $16 \mathrm{GW}$ by 2011 , this ambition of the India government is been put to the test due to the finances needed in the actualization of such giant stride. Indian power development is financed by both public and private investors. These consist of development banks, institutional investors, private sector and government collaboration in the form public-private partnership, commercial banks, equity investors etc.

\section{Conclusion}

This article explored literature on power infrastructure development in the Brazil and India. The explored literature showed that there are several approaches adopted by the Brazil and India government in the development of power infrastructture that has positively affected the horizon in terms of quality education, provision of quality health care, employment, wealth creation. This has confirmed the literature that stated that secured energy would aid nation's development in terms of GDP and also boost regional growth, reduce social related crisis, eradicate poverty and unemployment.

\section{References}

1. Unit, E.I., 2009. E-readiness rankings 2009: The usage imperative. The Economist. A report from the Economist Intelligence Unit written in cooperation with the IBM Institute for Business Value. 
2. EPE (2014b), Ten Year Energy Expansion Plan 2023, Rio de Janeiro.

3. E.P.E (2014). Brazilian energy balance 2014 year 2013, Rio de Janeiro, a.

4. Horner, N., Horner, N., de Paula Oliveira, Antonio Geraldo, de Paula Oliveira, Antonio Geraldo, Silberglitt, R., Silberglitt, R., Khaled Poppe, M., Khaled Poppe, M., Bressan Rocha, B. \& Bressan Rocha, B. (2016). Energy foresight, scenarios and sustainable energy policy in Brazil. Foresight, 18(5):535-550.

5. Organisation for Economic Co-operation, Development, and International Energy Agency (2013), "Brazil energy outlook", World Energy Outlook, OECD/IEA, Paris, pp. 301-417.

6. EPE (2007), Brazilian Energy Plan 2023, Rio de Janeiro.

7. Spatuzza, A. (2014). Brazil wind capacity factor at $50 \%$. Recharge, 21.

8. Victor,D.G. \& Heller,T.C. (2007). The political economy of power sector reform: the experiences of five major developing countries Cambridge University Press.

9. Oliveira, C., Zulanas, C. \& Kashiwagi, D. (2016). A long-term solution to overcome the problems caused by droughts in the Brazilian power systems. Procedia engineering, 145948-955.

10. EIA, (2014, June 17). Hydropower supplies more than three-quarter of Brazil's electric power. U.S. Energy Information Administration. Retrieved May 23, 2015.

11. Petroleum, B., 2015. BP Statistical Review of world energy 2015. Statistical review of world energy, 2016, p.65.

12. Liming, H. (2009). Financing rural renewable energy: A comparison between china and india. Renewable and sustainable energy reviews, 13(5):1096-1103.

13. Amaral, S. and D'Alge, J.C.L., 2009. Spatial data availability and its implications for sustainable development of the Brazilian Amazon. Earth science informatics, 2(4), pp.193-203.

14. De Pesquisa Energética, E. (2007). Plano nacional de energia 2030-PNE 2030. Rio de janeiro: EPE/MME.

15. IHU, Instituto Humanitas Unisinos. 2014. 'MME prevê necessidade de novas usinas nucleares'. 12 February. [LINK].

16. Luomi, M. (2014). Sustainable energy in BrazilReversing past achievements or realizing potential.

17. Runhaar, H., Driessen, P. \& Vermeulen, W. (2005). Policy competences of environmental sustainability professionals. Greener international, (49):25.

18. Martins, F.R. \& Pereira, E.B. (2011). Enhancing information for solar and wind energy technology deployment in Brazil. Energy policy, 39(7):43784390.

19. Vichi, F.M. \& Mansor, M.T.C. (2009). Energia, meio ambiente e economia: $\mathrm{O}$ brasil no contexto mundial. Química nova, 32(3):757-767.

20. Meltzer, J.P. (2016). Financing low carbon, climate resilient infrastructure: The role of climate finance and green financial systems.

21. PBMC, Painel Brasileiro de Mudancas Climáticas. 2013. Sumário Executivo. Mitigacão das Mudancas Climáticas. Contribuicão do Grupo de Trabalho 3 ao Primeiro Relatório de Availiacão Nacional do Painel Brasileiro de Mudancas Climáticas. Brasília, DF.

22. Yi-Chong, X., 2004. Electricity Reform in China, India and Russia. Books.

23. Siddhartha Potluri, S. \& Rajan A, T. (2010). Merchant power plants in India: Risk analysis-using simulation. International journal of energy sector management, 4(1):87-112.

24. Ranganathan,V. (1997). International Energy Markets, Competition and Policy, 18th USAEE/IAEE North American Conference, 1997. Conference proceedings of the Xth conference held in Y. International Association for Energy Economics.

25. CEA Data from available at: $\underline{\text { www.cea.nic.in }}$ (accessed 20 April 2017).Chaudhary, A., Krishna, C. \& Sagar, A. (2015). Policy making for renewable energy in india: Lessons from wind and solar power sectors. Climate policy, 15(1):58-87.

26. Koppenjan, J.F. and Enserink, B., 2009. Publicprivate partnerships in urban infrastructures: reconciling private sector participation and sustainability. Public Administration Review, 69(2), pp.284-296.

27. PFC (2009), Report on State Power Utilities, Power Finance Corporation, New Delhi, available at hhtp://pfc.gov.in/report_spu.pdf, 2008.

28. Nelson, D., Shrimali, G., Goel, S., Konda, C. \& Kumar, R. (2012). Meeting India's renewable energy targets: The financing challenge. CPI-ISB report, climate policy initiative (www.climatepolicyinitiative.org),

29. Shrimali, G., Nelson, D., Goel, S., Konda, C. \& Kumar, R. (2013). Renewable deployment in india: Financing costs and implications for policy. Energy policy, 6228-43.

30. Planning Commission, Government of India, 2008a Eleventh Five-Year Plan (2007-12). Volume 1: inclusive growth. Oxford University Press, Delhi.

31. Garg, P. (2012). Energy scenario and vision 2020 in India. Journal of sustainable energy \& environment, 3(1).

32. BP, 2012. BP statistical review of World energy, 2012. Available at: (http://www.bp.com/sectionbodycopy.do?categoryId $=7500 \&$ contentId $=7068481$ 
33. McCrone, A., Usher, E., Sonntag-O'Brien, V., Moslener, U. \& Grüning, C. (2012). Global trends in renewable energy investment 2012. Frankfurt school UNEP collaborating centre for climate and sustainable energy finance.

34. Initiative, C.P., Nelson, D., Shrimali, G., Goel, S., Konda, C. \& Kumar, R. (2012). Meeting India's renewable energy targets: The financing challenge. Climate policy initiative, San Francisco, USA.

35. Gupta, J.P. \& Sravat, A.K. (1998). Development and project financing of private power projects in developing countries: A case study of India. International journal of project management, 16(2):99-105.

36. Chowdhury, A.N. \& Charoenngam, C. (2009). Factors influencing finance on IPP projects in asia: A legal framework to reach the goal. International journal of project management, 27(1):51-58.

37. Chowdhury, S., Sumita, U., Islam, A. and Bedja, I., 2014. Importance of policy for energy system transformation: Diffusion of PV technology in Japan and Germany. Energy policy, 68, pp.285-293.
38. Singh, R. \& Sood, Y.R. (2011). Current status and analysis of renewable promotional policies in Indian restructured power sector-a review. Renewable and sustainable energy reviews, 15(1):657-664.

39. Reserve Bank of India (RBI) (2014), "Risk management systems in banks", available at: hhtp://rbidocs.rbi.org.in/ (accessed 1 June 2017).

40. Bhattacharyay, B. (2010). Estimating demand for infrastructure in energy, transport, telecommunications, water, and sanitation in Asia and the pacific: $2010-2020$.

41. Bhattacharyay, B.N. (2012). Estimating demand for infrastructure, 2010-2020. Infrastructure for Asian connectivity, 19.

42. Tortajada, C. (2016). Policy dimensions of development and financing of water infrastructure: The cases of china and India. Environmental science \& policy, 64177-187.

43. Heller, T.C., Tjiong, H.I. \& Victor, D.G. (2003). Electricity restructuring and the social contract. Program on energy and sustainable development, estados unidos, stanford university, working paper, (15). 